\title{
KECERNAAN IN-VITRO TANAMAN KALIANDRA (Calliandra calothyrsus) BERBUNGA MERAH DAN PUTIH
}

\author{
Anak Agung Ayu Sri Trisnadewi dan I Gusti Lanang Oka Cakra \\ Fakultas Peternakan Universitas Udayana \\ e-mail : dewitrisna26@yahoo.com
}

\begin{abstract}
ABSTRAK
Penelitian bertujuan untuk mengetahui perbedaan produk fermentasi rumen dan kecernaan in-vitro antara kaliandra (Calliandra calothyrsus) berbunga merah dan putih. Untuk mengetahui perbedaan nilai tengah dilakukan dengan menggunakan t-test (unpairing t-test with equal replicate) dan masing-masing diulang sebanyak sepuluh kali sehingga terdapat dua puluh unit percobaan. Peubah yang diamati antara lain: $\mathrm{pH}$, kadar ammonia, VFA, kecernaan bahan kering (KCBK) serta kecernaan bahan organik (KCBO) cairan rumen in-vitro. Hasil penelitian menunjukkan bahwa nilai $\mathrm{pH}$, konsentrasi $\mathrm{NH}_{3}$, dan konsentrasi VFA parsial dan total kaliandra berbunga merah cenderung lebih rendah daripada kaliandra berbunga putih tetapi secara statistik berbeda tidak nyata. Kecernaan bahan kering dan bahan organik pada kaliandra berbunga merah nyata lebih rendah daripada kaliandra berbunga putih. Dari hasil penelitian dapat disimpulkan bahwa kaliandra berbunga merah mempunyai $\mathrm{pH}, \mathrm{NH}_{3}$, VFA parsial dan total, kecernaan bahan kering dan bahan organik in-vitro yang lebih baik dibandingkan dengan kaliandra berbunga putih..
\end{abstract}

Kata kunci: kaliandra, amonia, vollatile fatty acid, kecernaan in-vitro

\begin{abstract}
The experiment is aimed to evaluate the different of rumen fermentation product and in-vitro digestibility of Calliandra calothyrsus with red and white flower. The different means is analized with t-test (unpairing t-test with equal replicate) and replicate ten times each. Variables observed are $\mathrm{pH}, \mathrm{NH}_{3}$, VFA parsial and total, dry matter and organic digestibility in-vitro. Results of the experiment showed that $\mathrm{pH}$ value, $\mathrm{NH}_{3}$ concentration and VFA partial and total on Calliandra calothyrsus with red flower tend to lower compared with white one but statistically not significant different. Dry matter and organic digestibility in-vitro of Calliandra calothyrsus with red flower is significantly lower than white one. It could be concluded that rumen fermentation product and dry matter and organic matter digestibility in-vitro of Calliandra calothyrsus with red flower is better than white one.
\end{abstract}

Keywords: Calliandra calothyrsus, ammonia, vollatile fatty acid, in-vitro digestibility

\section{PENDAHULUAN}

Pemberian pakan hijauan pada ternak ruminansia tetap dibutuhkan baik sebagai sumber energi maupun sumber protein. Hijauan mempunyai kandungan nutrisi yang berbeda antara hijauan satu dengan lainnya sehingga ternak perlu diberikan hijauan yang berbeda sehingga kebutuhan akan nutrisi dapat terpenuhi.

Kaliandra (Calliandra calothyrsus) merupakan legum yang sudah biasa diberikan pada ternak sebagai hijauan sumber protein. Kaliandra merupakan tanaman yang mempunyai bentuk berupa pohon kecil atau perdu yang termasuk kedalam keluarga leguminosae. Salah satu species yang masuk ke Pulau Jawa adalah species Calliandra calothyrsus berbunga merah dan Calliandra calothyrsus berbunga putih (Mulyana et. al., 2006). Produktivitas kaliandra merah sebagai pakan tergantung dari beberapa faktor diantaranya ketinggian tempat, curah hujan dan cara penanaman. Sebagian besar peneliti melaporkan bahwa kaliandra merah dalam keadaan segar cukup palatable untuk ternak, terutama bagi ternak yang tidak pernah diberikan, dan mungkin terdapat perbedaan palatabilitas di antara berbagai provenan kaliandra (Karda, 2011).

Salah satu faktor yang mempengaruhi nilai gizi adalah kecernaannya, dan sejauh mana hijauan ternak dapat dicerna dan diserap oleh ternak. Permasalahan kaliandra sebagai pakan ternak adalah kadar tannin yang tinggi sehingga mempunyai tingkat kecernaan yang rendah (30-60\%) (Roshetko, 2006). Selanjutnya Paterson (2001), menyatakan kecernaan kaliandra sangat bervariasi, dari sekitar 30\% sampai $60 \%$.

Tangendjaja et al. (1992) mendapatkan bahwa domba dan kambing akan tumbuh lebih baik bila disuplementasi dengan kaliandra dibandingkan bila hanya diberi rumput. Tingkat suplementasi yang baik adalah 30\% dari total ransum karena pemberian yang lebih tinggi tidak mempunyai pengaruh lagi.

Kandungan nutrisi terutama protein yang cukup tinggi pada kaliandra sangat cocok untuk pakan 
ternak ruminansia, tetapi di lain pihak kandungan zat antinutrisi berupa tannin yang cukup tinggi akan berpengaruh terhadap kecernaannya. Disamping itu, pengalaman yang terjadi di masyarakat kaliandra sudah biasa diberikan pada ternak dan umumnya kaliandra yang berbunga merah lebih disukai (palatable) oleh ternak dibandingkan dengan yang berbunga putih. Tujuan penelitian adalah mengetahui perbedaan kecernaan in-vitro kaliandra (Calliandra calothyrsus) berbunga merah dan putih.

\section{MATERI DAN METODE}

\section{Materi:}

Bahan yang digunakan adalah daun kaliandra (Calliandra calothyrsus) berbunga merah dan putih yang diperoleh di Desa Pempatan, Karangasem serta cairan rumen untuk penelitian in-vitro. Penelitian dilakukan di Laboratorium Balai Penelitian Ternak Ciawi Bogor.

\section{Metode:}

Perbedaan rataan nilai tengah penelitian dilakukan dengan menggunakan t-test dan masing-masing perlakuan atau bahan (kaliandra berbunga merah dan putih) diulang sebanyak 10 kali.

\section{Peubah yang diamati:}

Peubah yang diamati dalam penelitian ini adalah: pH, kadar ammonia, kadar VFA, kecernaan bahan kering dan organik (KCBK dan KCBO) ransum dalam cairan rumen in-vitro.

Cara Perhitungan:

1. Koefisien Cerna Bahan Kering (KCBK) dan Koefisien Cerna Bahan Organik (КСBO):

$$
\% \mathrm{KCBO}=\frac{\text { BOsampel }(g)-\text { BOresidu }(g)-\text { BOBlanko }(g)}{B O \text { sampel }(g)} X 100 \%
$$

2. Kadar $\mathrm{NH}_{3}$ Supernatan:

$$
\operatorname{KadarNH} 3(m M)=\frac{m l H 2 S O 4 x N H 2 S O 4 x 1000}{\operatorname{sampel}(g) x B k \operatorname{sampel}(\%)}
$$

3. Produksi VFA total dihitung:

$$
\operatorname{VFAtotal}(m M)=\frac{(a-b) x N H C l \times 1000 / 5 m M}{\operatorname{Sampel}(g) x B k \operatorname{Sampel}(\%)}
$$

Keterangan rumus:

a: volume titran blanko

b: volume titran contoh

\section{Analisis Data}

Data yang diperoleh pada penelitian ini dianalisis dengan menggunakan unpairing t-test with equal replicate (Steel and Torrie, 1991).

\section{HASIL DAN PEMBAHASAN}

Tingkat keasaman $(\mathrm{pH})$ dari kaliandra berbunga merah 2,16\% lebih tinggi tetapi secara statistik berbeda tidak nyata $(\mathrm{P}>\mathrm{O}, \mathrm{O} 5)$ dibandingkan dengan kaliandra berbunga putih (Tabel 1). Peningkatan pH kemungkinan disebabkan karena menurunnya perombakan karbohidrat terlarut dengan adanya tanin pada kaliandra. Menurut Owen dan Goetsch (1988) kisaran $\mathrm{pH}$ normal yaitu 5,5-7,2 sedangkan hasil penelitian menunjukkan angka yang sedikit lebih tinggi.

Tabel 1. Konsentrasi pH, NH3, VFA, KCBK, dan KCBO Kaliandra Berbunga Merah dan Putih

\begin{tabular}{lrr}
\hline \multirow{2}{*}{ Peubah } & \multicolumn{2}{c}{ Jenis Kaliandra } \\
\cline { 2 - 3 } $\mathrm{pH}$ & $7,41 \pm 0,06 \mathrm{a}$ & $7,25 \pm 0,07 \mathrm{a}$ \\
$\mathrm{NH}_{3}(\mathrm{mM})$ & $20,87 \pm 1,25 \mathrm{a}$ & $23,85 \pm 1,50 \mathrm{a}$ \\
VFA parsial: & & \\
Asam asetat (mM) & $22,11 \pm 4,26 \mathrm{a}$ & $31,76 \pm 1,69 \mathrm{a}$ \\
Asam propionat $(\mathrm{mM})$ & $7,64 \pm 1,16 \mathrm{a}$ & $11,21 \pm 1,31 \mathrm{a}$ \\
Asam iso butirat $(\mathrm{mM})$ & $1,39 \pm 0,26 \mathrm{a}$ & $1,84 \pm 0,26 \mathrm{a}$ \\
Asam n butirat $(\mathrm{mM})$ & $2,11 \pm 0,46 \mathrm{a}$ & $2,64 \pm 0,17 \mathrm{a}$ \\
Asam iso valerat $(\mathrm{mM})$ & $2,35 \pm 0,36 \mathrm{a}$ & $2,78 \pm 0,47 \mathrm{a}$ \\
Asam n valerat $(\mathrm{mM})$ & $1,91 \pm 0,26 \mathrm{a}$ & $2,27 \pm 0,45 \mathrm{a}$ \\
VFA total & $37,57 \pm 6,96 \mathrm{a}$ & $52,50 \pm 3,79 \mathrm{a}$ \\
KCBK (\%) & $64,74 \pm 1,65 \mathrm{a}$ & $78,63 \pm 1,35 \mathrm{~b}$ \\
KCBO (\%) & $65,39 \pm 2,34 \mathrm{a}$ & $86,96 \pm 1,02 \mathrm{~b}$ \\
\hline
\end{tabular}

Keterangan:

Huruf yang berbeda pada baris yang sama menunjukkan perbedaan yang nyata $(P<0,05)$

Kadar amonia $\left(\mathrm{NH}_{3}\right)$ cairan rumen pada kaliandra berbunga merah dan putih menunjukkan perbedaan yang tidak nyata $(\mathrm{P}>0,05)$ walaupun kadar $\mathrm{NH}_{3}$ kaliandra berbunga merah $14,28 \%$ lebih rendah dibandingkan dengan kaliandra berbunga putih. Hal ini terjadi karena adanya kandungan tannin dan kondens tanin pada kaliandra berbunga merah yang nyata lebih tinggi dibandingkan dengan kalindra berbunga putih. Trisnadewi dan Cakra (2014) mendapatkan kandungan tanin dan kondens tanin masing-masing 89,03\% dan $85,19 \%$ nyata $(\mathrm{P}<0,05)$ lebih tinggi pada kaliandra berbunga merah dibandingkan dengan kaliandra berbunga putih. Kadar tanin yang tinggi pada kaliandra berbunga merah diimbangi dengan kadar kondens tanin yang juga lebih tinggi sehingga dapat digunakan sebagai protektor bagi protein yang mudah larut. Tanin maupun kondens tanin akan mengikat protein yang ada dalam kalindra sehingga akan menghambat degradasinya di dalam rumen. Hal ini sesuai dengan pendapat Winugroho dan Widiastuti (2009) mendapatkan bahwa degradasi protein kaliandra dalam ransum dihambat oleh tanin sehingga banyak protein yang tidak termanfaatkan oleh ternak dan lebih dari $66 \%$ terbuang dalam feses. Produksi $\mathrm{NH}_{3}$ berasal dari protein yang didegradasi oleh enzim proteolitik. Kadar amonia dalam rumen merupakan petunjuk antara proses degradasi dalam rumen dan proses sintesis protein oleh mikroba rumen. Jika pakan defisien akan protein atau proteinnya tahan degradasi maka konsentrasi amonia dalam rumen akan rendah dan pertumbuhan mikroba rumen akan lambat yang akan menyebabkan turunnya kecernaan pakan (McDonald et al., 1988).

Kecernaan bahan kering (KCBK) dan kecernaan 
bahan organik (KCBO) kaliandra berbunga merah masing-masing $21,46 \%$ dan $32,99 \%$ nyata $(\mathrm{P}<0,05)$ lebih rendah dibandingkan dengan kaliandra berbunga putih (Tabel 1). Hal ini terjadi karena adanya kandungan tanin dan kondens tanin yang nyata lebih besar pada kaliandra berbunga merah dibandingkan dengan kaliandra berbunga putih. Tanin merupakan penghambat dari mikroba rumen sehingga kecernaannya menjadi lebih kecil. Winugroho dan Widiastuti (2009), melakukan penelitian pada domba membandingkan kecernaan bahan kering antara kaliandra, leucaena, gliricidia dan rumput gajah mendapatkan bahwa kecernaan kaliandra 59\% nyata paling kecil dibandingkan dengan kecernaan hijauan lainnya. Paterson (2001) menyatakan kecernaan kaliandra sangat bervariasi dari sekitar 30\% sampai $60 \%$, sedangkan kecernaan bahan kering dan organik hasil penelitian cenderung lebih tinggi. Hasil kecernaan bahan organik sejalan dengan kecernaan bahan kering, hal ini karena kadar bahan organik terdapat dalam bahan kering sehingga hasil kecernaan bahan organik sejalan dengan kecernaan bahan kering.

Kadar VFA parsial yaitu asam asetat, propionat, iso butirat, $\mathrm{n}$ butirat, iso valerat, dan $\mathrm{n}$ valerat pada kaliandra berbunga merah masing-masing $43,65 \%$, $46,73 \%$, 32,37\%, 25,12\%, 18,30\%, dan 18,85\% lebih rendah tetapi secara statistik berbeda tidak nyata $(\mathrm{P}>0,05)$ bila dibandingkan dengan kaliandra berbunga putih. Begitu juga dengan VFA total menunjukkan perbedaan yang tidak nyata $(\mathrm{P}>0,05)$ antara kaliandra berbunga merah dan putih (Tabel 1). Produksi VFA sangat tergantung pada kecernaan serat kasar atau bahan kering dari bahan pakan. KCBK pada kaliandra berbunga merah lebih kecil dibandingkan dengan KCBK berbunga putih. Hal ini menyebabkan produksi VFA baik VFA parsial maupun total pada kaliandra berbunga merah lebih kecil dibandingkan dengan produksi VFA in-vitro kaliandra berbunga putih. Karbohidrat akan difermentasi oleh mikroba rumen membentuk VFA yang merupakan sumber energi siap pakai bagi mikroba rumen atau induk semang. Pembentukan VFA dalam rumen sangat penting mengingat $70-85 \%$ energi ruminansia bersumber dari VFA (Ginting, 2005).

\section{SIMPULAN}

Dari hasil penelitian ini dapat disimpulkan bahwa kaliandra berbunga merah mempunyai kecernaan bahan kering dan bahan organik dalam cairan rumen in-vitro yang lebih rendah sehingga bisa dimanfaatkan oleh ternak setelah melewati rumen.

\section{UCAPAN TERIMAKASIH}

Penulis mengucapkan terimakasih kepada Universitas Udayana atas dana yang diberikan melalui penelitian hibah bersaing tahun 2014 .

\section{DAFTAR PUSTAKA}

Ginting, S.P. 2005. Sinkronisasi degradasi protein dan energi dalam rumen untuk memaksimalkan produksi protein mikroba.Wartazoa. 15(1): 1-10.

Karda, I W., 2011. Kaliandra Merah Dalam Sistem Pertanian Konservai peluang, Kendala dan Solusi. Udayana University Press.

McDonald, P., R. A. Edwards, dan J. F. D. Greenhalgh. 1988. Animal Nutrition. $4^{\text {th }}$ Edition. New York : Longman Scientific \& Technical.

Mulyana, A., Sumarta, T. Hidayat, dan Karma. 2006. Produktivitas Beberapa Varietas Kaliandra (Calllandra calothyrsus) sebagai Hijauan Pakan Ternak. Temu Teknis Nasional Tenaga Fungsional Pertanian. Pusat Penelitian dan Pengembangan Peternakan.

Owens, F.N. dan A. L. Goetsch. 1988. Ruminal Fermentation. In D.C. Church Ed. The Ruminant Animal Digestive Physiology and Nutrition. A Reston Book. Prentice Hall. Eglewood Cliffs, New Jersey.

Paterson, R., B. Palmer, M. Shelton, R. Merkel, T. M. Ibrahim, R. Arias, K. Berhe, dan A. N. F. Perera. 2001. Produksi Hijau Ternak. Dalam: Produksi dan Pemanfaatan Kaliandra (Calliandra calothyrsus) Pedoman Lapang. Editor: Stewart, J., Mulawarman, J. M. Roshetko, M. H. Powell. Terjemahan: SN Kartikasari. Winrock International Institute for Agricultural Development.

Roshetko, J. M., D. Lesueur, dan Sarrailh, J. 2001. Penanaman. Dalam: Produksi dan Pemanfaatan Kaliandra (Calliandra calothyrsus) Pedoman Lapang. Editor: Stewart, J., Mulawarman, J. M. Roshetko, M. H. Powell. Terjemahan: SN Kartikasari. Winrock International Institute for Agricultural Development.

Steel, R. G. D., and J. H. Torrie. 1989. Prinsip dan Posedur Statistik Suatu Pendekatan Biometrik. Edisi Kedua. Alih bahasa B. Sumantri. Jakarta. Gramedia.

Tangendjaja, B., E. Wina, B. Palmer dan T. Ibrahim (penyunting) 1992. Kaliandra dan pemanfaatannya. ACIAR dan Balitnak.

Trisnadewi, A. A. A. S. dan Cakra, I G. L. O. 2014. Evaluasi Kualitas Nutrisi Tanaman Kaliandra (Calliandra calothyrsus) Berbunga Merah dan Putih. Prosiding Seminar Nasional Sains dan Teknologi 2014. Denpasar. Lembaga Penelitian dan Pengabdian kepada Masyarakat Universitas Udayana.

Winugroho, M. dan Y. Widiastuti. 2009. Keseimbangan nitrogen pada domba yang diberi daun leguminosa sebagai pakan tunggal. Bulletin Ilmu Peternakan dan Perikanan. Vol XIII (1). 